\title{
Analysis of the Inheritance and Development of the Original Ecological Dance in China -Research Special Project of Research Service Base of Heilongjiang Provincial Education
}

\author{
Li Jingbo, Cong Yongzhu
}

Heihe College, Heilongjiang, China

Keywords: original ecological dance; inheritance

\begin{abstract}
Culture cannot be achieved by any other historical component. In culture,there is also an unusual star, dance. "Dance" draws from "music" by means of "dance". "Music" is a comprehensive art form, reflecting the deeper social value of national spirit and the psychological structure of social culture. Researching and developing traditional dance has become a great task for the dance researchers and performers. This paper hopes to find out the experience that traditional dance can learn from inheritance and development through the analysis of traditional dance. However, it shall been clearly seen that, although more and more original ecological arts have come out of the gully and appear on the major literary and artistic platforms, the rapid development of modern civilization has also made the original ecological art assimilated and alienated, and the wheel of history is "crushed to dust" by the wheel of history. How many children remember the beautiful legend? The problem is becoming more and more urgent and action is imperative. More effective measures shall be taken to protect the original ecological culture, contribute more effective protection methods, and try to save and preserve the original ecological culture of the folk.
\end{abstract}

\section{Introduction}

With the development of China's political and economic development, China has also joined the "WTO" international economic and Trade Organization. A unified and integrated economy is quietly affecting all areas of China. With the coming of foreign culture, the collision and blend of Chinese and Western cultures made Chinese cultural life colorful in 80s. With the fast pace of life, the aesthetic needs, the new thinking concept, the pursuit of faith and love, emotional expression have taken place completely different, changing, the folk culture characteristics of the nation is also gradually changing. Apart from major festivals, it is difficult to distinguish the characteristics of ethnic groups in form. Although there has been such a great change, but because of the existence of the nation, the modern way of life and cultural characteristics of its own nation have changed greatly compared with the past, but can it be called the character of the nation? Of course not. Although the history of the culture is facing the modern science and technology is really under great pressure, but this is also the only way to stand up to our own heel to straighten the waist, only to preserve their own culture, to truly absorb foreign culture. The external pressure must force the folk dance to change the traditional model, and display the new creative thinking and structure with a new aesthetic principle and artistic principle, and then express it by the dance language.

\section{Analysis of the Current Status of Original Ecological Dance}

The original ecology, a noun that appears to be new, was spread overnight in various media, but it was a misconception that had appeared in the 1960s, but at that time the "original ecology" had not been used in culture, but was first accepted and made by the biological community. Use. We seem to be able to explain this: This is a form of art that has not been "corroded" by modern scientific and technological means, relying only on the way of folk oral and oral instruction, which is almost primitive and has a strong local flavor. 


\subsection{The roots seeking of original ecological dance}

As the concept of "original ecology" is applied to the world of culture in the field of biology, the research methods of biological circles are also cited by the cultural circles. All the cultural and artistic things which have been born in the natural condition and with the true features of culture are all retained, which forms the variety of forms we see now. The original ecological art. With the deepening of research, China has gradually joined the research of original ecological culture. The Chinese art circles in the 8,90 era focused their attention on the original eco dance, which made the original eco dance develop at this stage. Since then, thematic treatises on dance ecology have been published continuously, which also reflects the rise of dance research in China. At the same time, some people have taken active exploration and Research on the choreography of folk dance, but their exploration and research generally stay in the creation of this simple aspect, that is, to dig out the essence of the original folk dance from the original folk dance, and to make a summary and improvement, at the same time, the essence of these parts is carried out.

\subsection{The history recording of original ecological dance}

In fact, "original ecology" is also a relative word, which corresponds to the word "industrialization" in science and technology society. Contrary to the reality of the industrial society, human beings, even though they have made more progress in this increasingly comfortable society, the speed of life, the world become smaller and people can know more of the universe, but it is also found that this also makes people forget their original form of life. "Original nature" is composed of several aspects: the first is the fusion with nature, the two is distinct regionalism, and the three is of great sustainability. In a word, it is from the human nature, the human civilization, without the influence and infiltration of other "cultural circles", and the state of life in all kinds of human behavior.

\section{The Inheritance Significance of Original Ecological Dance}

\subsection{The primitive folk dance plays an important role in the history of cultural development.}

The folk dance culture of all nationalities has a long history and has a long history. Because of the reasons of historical development and the great differences of the development of all ethnic groups in China, there are also great differences in the development of the new China, and the social and economic development of all ethnic groups is extremely unbalanced. Therefore, the original folk dance culture of different nationalities reflects the characteristics of different stages of social development, and also highlights different national characteristics. Besides, our country has vast territory, and the North South span and the East West span are very wide. So it also determines the different culture characteristics of the nationalities in China.

\subsection{Historical and cultural aspects.}

The original folk dance culture of all nationalities in China has a long history and has its own characteristics. The original folk dance culture of all nationalities in China is a valuable cultural asset. In Yunnan and other places, sightseeing tourists continue to stream every year, which are attracted by the diverse and rich culture in those areas. It can be seen that, as a valuable cultural asset, the influence of the original folk dance culture is extraordinary. The attraction of folk dance culture of all ethnic groups should not be underestimated. From this point of view, the national traditional culture needs not only to show and propagate, but also to manage it as a resource that can create economic benefits, so as to achieve the common harvest and development of two aspects of social and economic benefits, and make it youth in the modern society and the world of modern civilization. The way out.

\subsection{Economic development.}

The original folk dance culture of all nationalities in China is inherited and developed among the masses. Folk dance, the culture of dance is closely related to the living habits, natural environment, 
production activities and religious beliefs of all nationalities. Influence, the original folk dance culture of all nationalities in China has formed its own characteristics in the long history of inheritance and development. Characteristics. Therefore, the original folk dance culture is a rich resource in the field of culture and art in China. This is in Yunnan and so on. Every year, many tourists visit and travel to Yunnan and other provinces. The culture of folk dance is rich in color and extraordinary cultural attraction. So we also have to reflect on it, that is, we treat it. The traditional culture of every ethnic group can't be operated merely as a way to display and publicize the traditional culture of a nation. We must grasp and develop resources for creating economic value.

\section{Conclusion}

Traditional dance is different from other forms of dance. It bears the accumulation of a thick traditional culture. In the time of the country's death, the traditional dance became the spiritual enjoyment of the people, which was far beyond the category of the dance and had multiple social values. The traditional dance has become a cultural phenomenon, from. Therefore, in the contemporary university education, it is necessary to strengthen the traditional culture education of the students, to make up the loopholes of the cultural accomplishment of the college students, to combine the traditional culture with the popular culture, and to expand the accumulation of College Students' culture.

This paper is Heilongjiang Provincial Department of education research business fee base research project.Number: 18KYYWFJD02. Project name: A study on the alienation of the original ecological dance of the Chinese and Russian peoples in the Heilongjiang River Basin

\section{References}

[1] Pu Yongguang. "My view on the protection of the contemporary folk dance of our country". Journal of Minzu University of China (PHILOSOPHY AND SOCIAL SCIENCE EDITION), fifth 2004, 84 - 86.

[2] Huang y. Yan. An attempt to introduce the original dance in the folk dance course in normal universities. The Journal of Yibin University is in 2009 eleventh, 124 - 126.

[3] Yi Liqing, Zhu He, Xiao Ling. The construction of the local dance course from the exploitation and utilization of the Nuo resources of Jiangxi. Journal of Beijing Dance Academy, second phase of 2010, 96 - 98.

[4] Ronaldo. Chinese folk dance move on cultural heritage J. Journal of Beijing Dance Academy, 2002 (1): 29. 